\title{
MODEL PENGATURAN PENGUNJUNG PADA KAWASAN WISATA ALAM PEGUNUNGAN DENGAN FUNGSI LINDUNG DAN INTENSITAS WISATA TINGGI DI KAWASAN WISATA KLUSTER GUNUNG PATUHA, KABUPATEN BANDUNG
}

\author{
Wanjat Kastolani, Fitri Rahmafitria \\ Dosen Fakultas Ilmu Pengetahuan Sosial, Universitas Pendidikan Indonesia \\ Email:wanjat_pci@yahoo.com
}

\begin{abstract}
Patuha Mountain Cluster is a part of South Bandung Region which has beautiful scenery of mountainous forest landscape. The uniqueness and its beauty become the main factors of its popularity as nature based tourism area. But the characteristic of mountainous region make this area stated by the government as preservation area (PP. No.72 th 2010), so the management should has specific program that appropriate for preservation function also for tourism purpose. This research is conducted to develop the visitor management concept of nature based area with preservation function and high visitor intensity. Visitor intensity is the frequent of use and visitor density analysis (Pfluger, Yvone (2004). Quantitative and qualitative methods were used to develop the visitor management model, and also by the spatial analysis to develop the map of preservation area. Visitor intensity was found by using carrying capacity analysis and survey method (questionnaire).

The result show that according to spatial and regulation analysis, all of the objects study in Patuha Mountain Cluster are categorized as preservation area. Most of them have medium visitor intensity, and one of it (Kawah Putih forest recreation), which is the most popular one has high visitor intensity. Identification of landscape characteristic and regulation of nature based area are the first step to develop an appropriate model of visitor management. Visitor density and visitor used also become the important factors that influence the environment quality of nature based tourism area. The high visitor intensity could pressure the physical condition of the area so the program of visitor management should implemented structurally. The development of interpretation program and media should be implemented especially to educate visitors to be more care and friendly with the environment. Another visitor management program that could implemented regarding this findings are limiting the accessibility to the main and sensitive attraction, activities decentralization and develop the tourism education program.
\end{abstract}

Keywords : Mountain based tourism, tourism intensity, visitor management

\section{PENDAHULUAN}

Selain keindahan panorama dan keunikan karakteristik lanskapnya, wilayah pegunungan juga memiliki tingkat kerawanan dari aspek kebencanaan. Karakteristik lanskap yang bergunung-gunung menjadikan sebagain besar wilayahnya masuk kedalam kategori lahan yang curam, sehingga rawan longsor. Ditambah dengan tingkat curah hujan rata-rata yang tinggi, membuat potensi bencana longsor juga makin tinggi.

Hal inilah yang menjadikan wilayah pegunungan sering ditetapkan sebagai kawasan lindung oleh pemerintah.
Berdasarkan Keputusan Presiden RI Nomor 32 Tahun 1990 tentang kawasan lindung, yang disebut sebagai kawasan lindung adalah kawasan yang ditetapkan dengan fungsi utama melindungi kelestarian lingkungan hidup yang mencakup sumber alam, sumber daya buatan dan nilai sejarah serta budaya bangsa guna kepentingan pembangunan yang berkelanjutan.

Pengelolaan kawasan dengan irisan fungsi lindung, berdaya dukung fisik rendah, memiliki fungsi vital bagi kehidupan masyarakat luas namun dimanfaatkan juga untuk tujuan wisata, menjadi sangat 
kompleks. Dimana pada fungsi lindung maka faktor pembatasnya adalah kemampuan alam dan lahan secara fisik dan biologis dalam suatu ruang ekosistem yang dinamis, sementara pada fungsi wisata, maka unsur bisnis dan nilai tambah ekonomi menjadi tujuan yang tidak kalah penting. Sehingga seringkali konflik kepentingan ini menjadikan bentuk pengelolaan kawasan wisata alam dengan fungsi lindung menjadi sering berbenturan dan sulit direalisasikan. Berkaitan dengan fenomena tersebut, maka penelitian ini disusun sebagai upaya untuk memberikan alternatif model pengaturan pengunjung pada kawasan wisata alam pegunungan dengan fungsi lindung dan berdaya dukung rendah. Lokasi penelitian adalah di wilayah kluster Gunung Patuha, yang merupakan wilayah pegunungan dengan banyak potensi daya tarik wisata namun memiliki fungsi lindung yang sangat vital, terkait dengan stabilitas tanah, daerah resapan air dan konservasi keanekaragaman hayati.

Penelitian ini dilakukan untuk memberikan alternatif model pengelolaan yang sesuai bagi kawasan pegunungan dengan fungsi lindung dan daya dukung fisik rendah. Tujuan penelitian ini adalah:

1. Menganalisis karakteristik alam dan daya dukung fisik dari kawasan lindung wilayah kluster Gunung Patuha, Kabupaten Bandung.

2. Menganalisis sebaran dan tingkat kepadatan pengunjung pada kawasan wisata di wilayah kluster Gunung Patuha, Kabupaten Bandung.

3. Melakukan analisis overlay berdasarkan karakteristik kawasan lindung dan intensitas wisata di wilayah kluster Gunung Patuha, Kabupaten Bandung.

4. Menentukan model pengaturan pengnjung yang sesuai untuk kawasan wisata alam pegunungan dengan fungsi lindung dan daya dukung rendah.

\section{METODOLOGI PENELITIAN}

Metode yang digunakan dalam penetian ini adalah penelitian deskriptif dengan jenis penelitian survey, yang terdiri dari tahapan pra survei, survei, analisis dan penyusunan model pengaturan pengunjung. Desain penelitian yang digunakan adalah sebagai berikut :

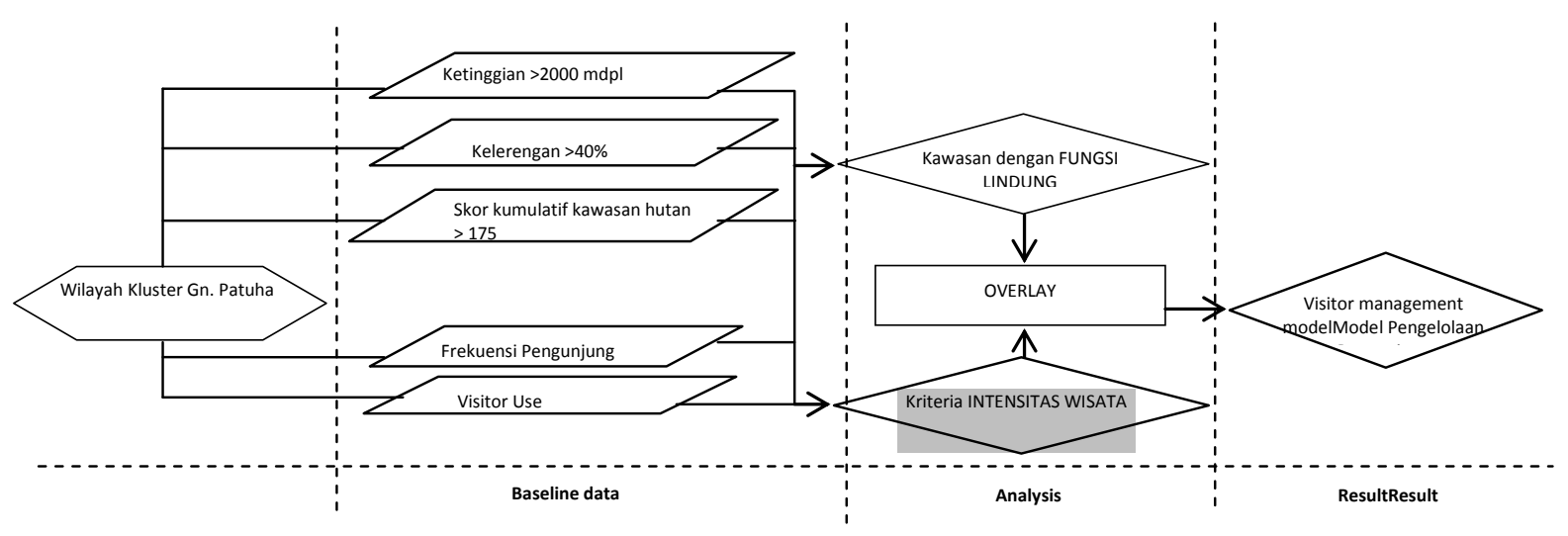

Gambar 1. Kerangka Pikir Penelitian

\section{Metode Analisis Data \\ a. Analisis Karakteristik Fungsi \\ Lindung \\ Parameter yang digunakan menginduk pada kriteria kawasan lindung yang dikeluarkan oleh Keputusan Presiden RI No.}

32 Tahun 1990 tentang Pengelolaan Kawasan Lindung. Adapun kriterianya adalah

- Kawasan hutan dengan factor-faktor lereng lapangan, jenis tanah, curah hujan yang melebihi nilai skor 175 . 
- Kawasan hutan dengan kelerengan lapangan $40 \%$ atau lebih

- Kawasan hutan yang memiliki ketinggian diatas permukaan laut 2000 meter atau lebih.

\section{b. Analisis Intensitas Wisata}

Parameter ini dipilih berdasarkan model yang dikembangkan oleh Pfluger, Yvone (2004) dalam mengembangan model visitor management di kawasan rekreasi alam Natura 2000, Lech River Valley, Austria. Adapun parameter intensitas wisata adalah :

- Visitor frequency : Tingkat kepadatan wisatawan pada beberapa lokasi wisata yang tersebar di wilayah kluster Gunung Patuha, Kabupaten Bandung

- Visitor use :Tingkat penggunaan kawasan wisata yang dikategorikan berdasarkan jenis aktivitas wisata dan dampaknya pada karakteristik fisik kawasan (fungsi lindung), di wilayah kluster Gunung Patuha, Kabupaten Bandung.

\section{c. Analisis Overlay}

Analisis ini dilakukan untuk menghasilkan ruang gabungan hasil analisis karakteristik fungsi lindung dengan intensitas wisata di wilayah Kluster Gunung Patuha.

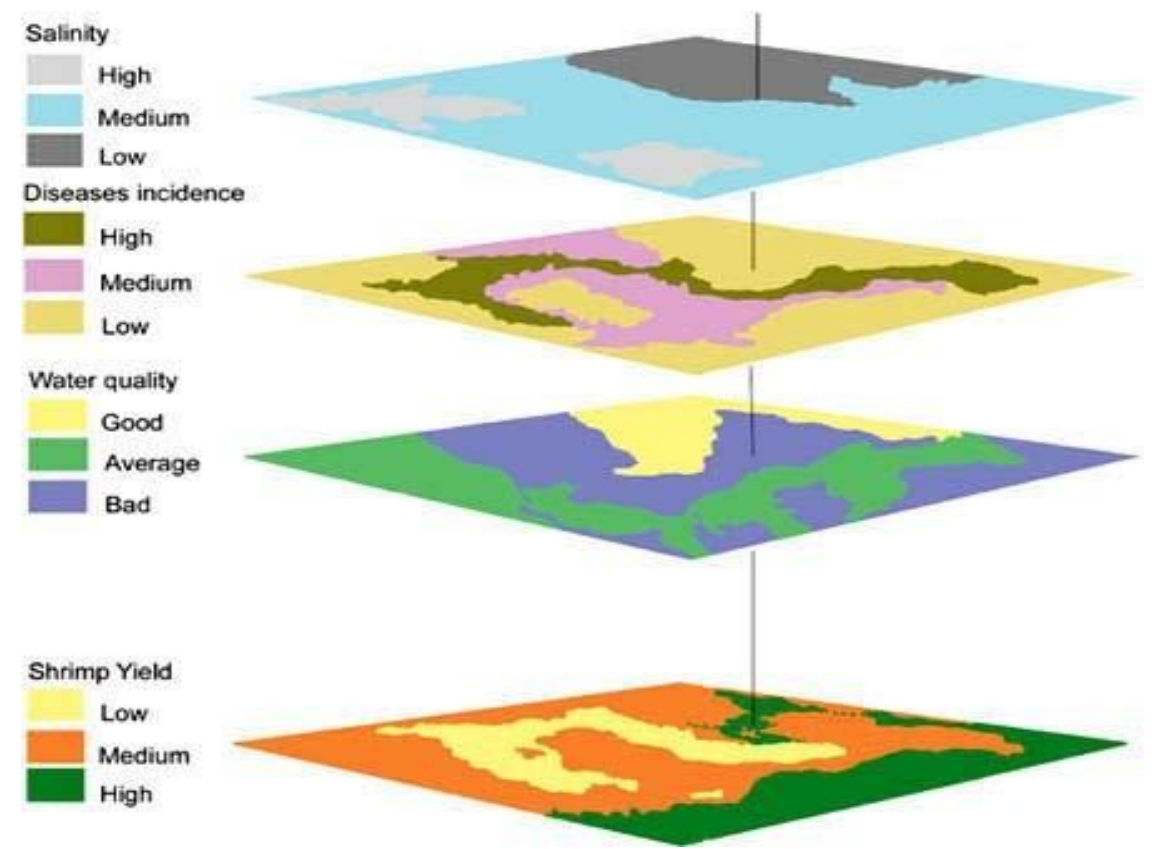

Gambar 2 Proses Overlay Peta Tematik

Sumber : FAO (2003)

\section{d. Penyusunan Model Pengaturan Pengunjung \\ Pada tahap ini dilakukan penyusunan} model pengaturan pengunjung yang ditentukan berdasarkan hasil overlay karakteristik kawasan lindung dan intensitas wisata. Kombinasi ruang yang diperoleh menjadi dasar dalam menentukan model pengaturan pengunjung dengan tujuan terjaganya fungsi lindung secara baik serta kenyamanan.

\begin{abstract}
HASIL DAN PEMBAHASAN
Kawasan Wisata Gunung Patuha merupakan salah satu kawasan wisata andalan yang terletak di sebelah selatan Kota Bandung. Kawasan wisata secara administratif pemerintahan, terletak di Kecamatan Rancabali Kabupaten Bandung. Lokasi Wisata yang termasuk kedalam area penelitian, diantaranya adalah Wana Wisata Kawah Putih, Bumi Perkemahan Ranca
\end{abstract}


Upas, Wisata Kampung Cai, Pemandian Air Panas Cimanggu serta Situ Patengan.

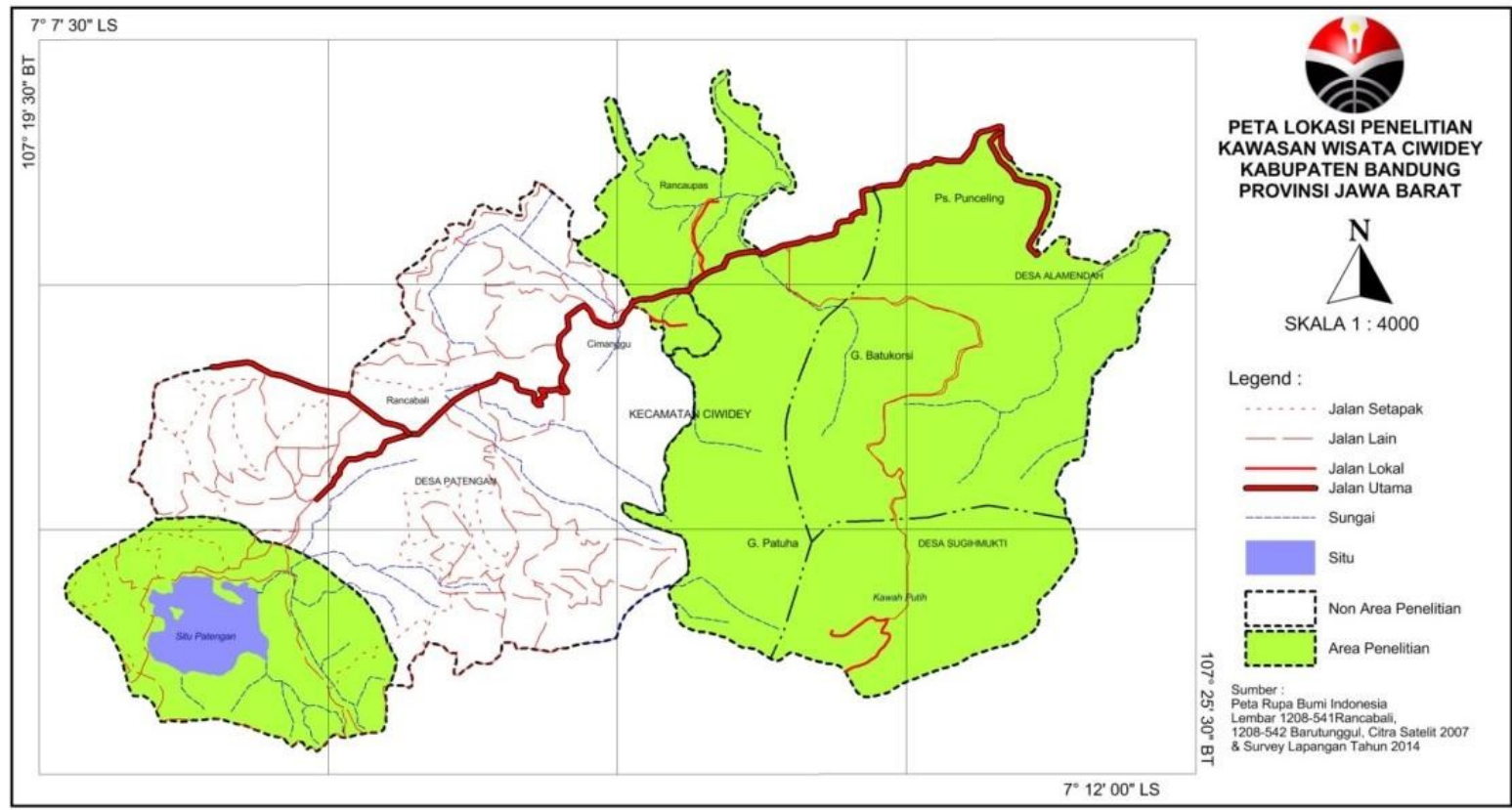

Gambar 3. Peta Lokasi Cluster Gunung Patuha

Sebaran Kawasan Lindung di Wilayah Kluster Gunung Patuha

Kawasan lindung merupakan kawasan yang harus tetap terjaga keaslian alamnya jangan sampai terganggu bahkan rusak.
Kawasan lindung dapat ditentukan dengan menggunakan standar yang telah ditetapkan oleh Menteri Pertanian melalui SK Mentan No. $837 / \mathrm{Kpts} / \mathrm{Um} / 11 / 1980$ dan diperkuat dengan Kepres No. 32/1990.

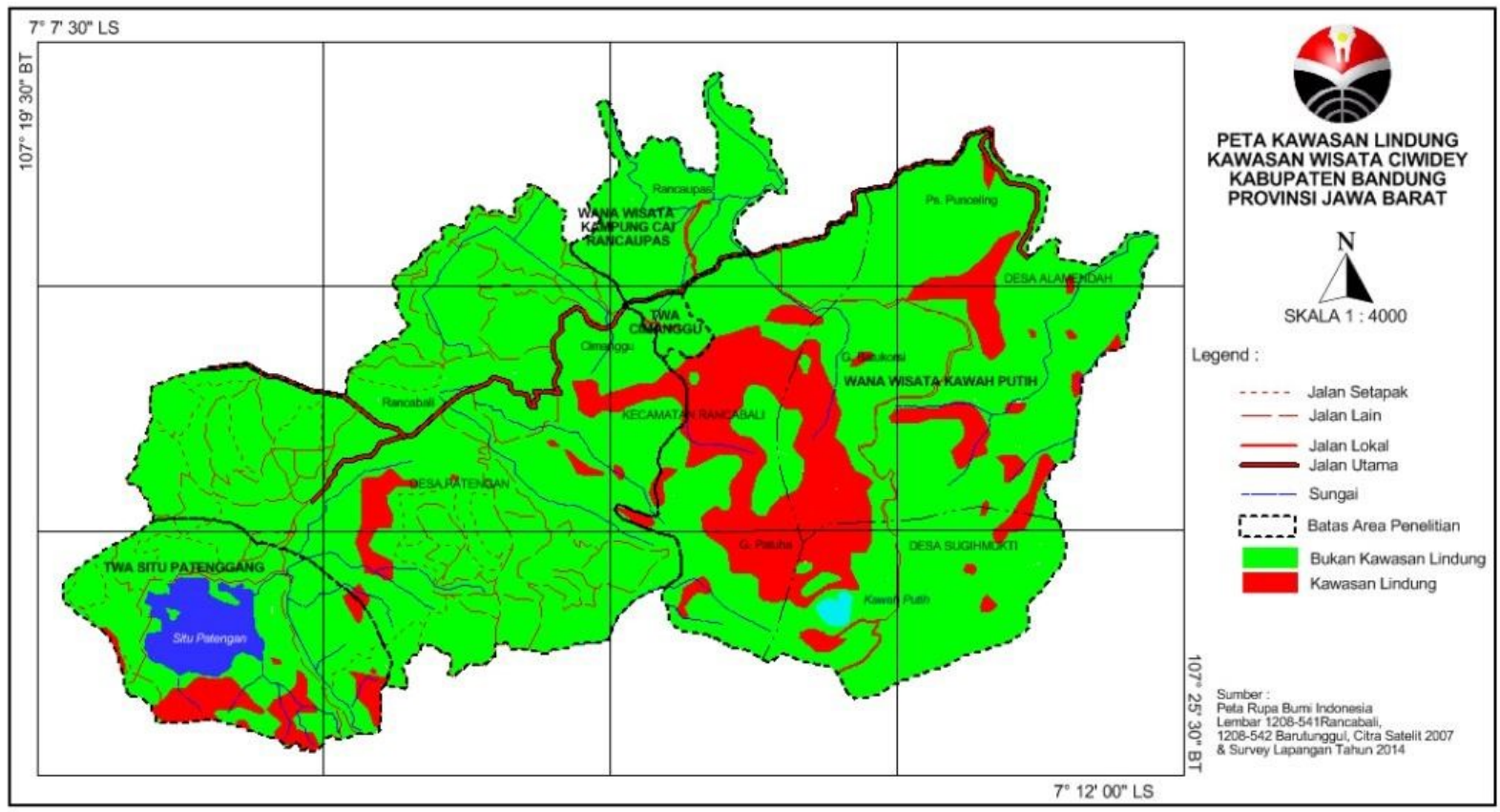

Gambar 4.Peta Kawasan Lindung Cluster Gunung Patuha 
Kawasan lindung di lokasi penelitian tersebar di bagian selatan dan timur cluster Gunung Patuha. Kawasan lindung terbesar terletak di wilayah Wana Wisata Kawah Putih yaitu $76 \%$ dari total luas kawasan, diikuti oleh TWA Cimanggu sebesar 12,4\% dan TWA Situ Patenggang sebesar 11,6\%.Bumi Perkemahan Ranca Upas tidak memiliki kawasan lindung.Namun demikian kajian juga dilakukan terhadap kebijakan pemerintah terkait penentuan fungsi kawasan hutan. Berdarkan PP no 72 tahun 2010 mengenai penentuan fungsi kawasan hutan, maka Wana Wisata Kawah Putih dan Bumi Perkemahan Ranca Upas merupakan kawasan lindung. Sementara TWA Cimanggu dan TWA Situ Patenggang merupakan kawasan konservasi yang pengelolaannnya diatur oleh PP. No 36 tahun 2010.

\section{Analisis Intensitas Wisata di Kawasan \\ Wisata Kluster Gunung Patuha}

a. Frekuensi Kunjungan Wisatawan

Frekuensi kunjungan wisatawan merupakan tingkat kepadatan wisatawan pada suatu kawasan wisata (Yvonne Pfluger, 2004).Tingkat kepadatan wisatawan dalam penelitian ini dihitung berdasarkan perbandingan antara standar kebutuhan ruang untuk berwisata dengan luasan areal pemanfaatan wisata di masing-masing kawasan wisata. Standar kebutuhan ruang dihitung dengan rumus yang dikemukakan oleh Douglas, W (2000), yaitu :

$$
\begin{aligned}
& A R=\frac{D x a}{C D \times T F \times 43,560} \\
& \text { Dimana, }
\end{aligned}
$$

\begin{tabular}{|c|c|c|c|c|c|c|}
\hline No & DTW & D & a & CD & TF & AR (Ha) \\
\hline 1 & WW Kawah Putih & 253,233 & 726 & 164 & 1.5 & 6.86 \\
\hline 2 & TWA Cimanggu & 118,864 & 302 & 164 & 1.5 & 1.34 \\
\hline 3 & Buper Ranca Upas & 32,100 & 907 & 164 & 1.0 & 1.63 \\
\hline 4 & TWA Situ Patengan & 166,263 & 544 & 164 & 2.0 & 2.53 \\
\hline
\end{tabular}

Berdasarkan hasil perhitungan dengan rumus diatas, maka diperoleh standar kebutuhan ruang untuk kegiatan wisata di masing-masing kawasan wisata adalah sebagai berikut :

Tabel 1.Standar kebutuhan ruang untuk kegiatan wisata di kawasan wisata kluster Gunung Patuha, Kabupaten Bandung

Tabel 2. Kategori tingkat kepadatan pengunjung di 4 kawasan wisata di kluster Gunung Patuha, Kabupaten Bandung

\begin{tabular}{clccc}
\hline No & \multicolumn{1}{c}{ DTW } & $\begin{array}{c}\text { Standar } \\
\text { kebutuhan ruang } \\
(\mathrm{Ha})\end{array}$ & $\begin{array}{c}\text { Luas Areal } \\
\text { pemanfaatan } \\
\text { wisata (Ha) }\end{array}$ & KATEGORI \\
\hline 1 & Wana Wisata Kawah Putih & 6.86 & 5.42 & Tinggi \\
2 & TWA Cimanggu & 1.34 & 4.5 & Rendah \\
3 & Bumi Perkemahan Ranca & 1.63 & 4.5 & Rendah \\
4 & Upas & 2.53 & 5.16 & Rendah \\
\hline
\end{tabular}

b. Tingkat Penggunaan oleh Wisatawan

Tingkat penggunaan (visitor use) pada kawasan wisata dikategorikan berdasarkan jenis aktivitas wisata dan dampaknya pada karakteristik fisik kawasan (fungsi lindung), di wilayah kluster Gunung Patuha, Kabupaten Bandung. Kriteria aktivitas intensif di kawasan wisata kluster Gunung Patuha, merupakan aktivitas utama wisata dengan tingkat kepadatan tinggi, berada 
pada areal daya tarik utama sehingga konsentrasi wisatawan tinggi. Dampak negative bagi kualitas lingkungan di areal ini, diamati cukup tinggi, khususnya dari jumlah sampah yang berserakan serta pemadatan tanah. Aktivitasnya meliputi piknik, melihat pemandangan, fotografi, makan minum. Dalam penelitian ini, juga dilakukan analisis terhadap perilaku wisatawan, yang dinilai melalui persepsi wisatawan terhadap perilaku sesama wisatawan lainnya.

Tabel 3. Persepsi Pengunjung terhadap Perilaku Wisatawan di Kawasan Wisata Alam Kluster Gunung Patuha

\begin{tabular}{|c|c|c|c|c|}
\hline \multirow[b]{2}{*}{ Perilaku Wisatawan } & \multirow[b]{2}{*}{$\begin{array}{c}\text { Wana } \\
\text { Wisata } \\
\text { Kawah } \\
\text { Putih }(n=50)\end{array}$} & \multirow[b]{2}{*}{$\begin{array}{c}\text { TWA } \\
\text { Cimanggu } \\
(n=34)\end{array}$} & \multirow[b]{2}{*}{$\begin{array}{l}\text { Buper } \\
\text { Ranca } \\
\text { Upas } \\
(n=37)\end{array}$} & \multirow[b]{2}{*}{$\begin{array}{c}\text { TWA Situ } \\
\text { Patenggan } \\
\mathrm{g}(\mathrm{n}=39)\end{array}$} \\
\hline & & & & \\
\hline Perilaku wisatawan membuang sampah & 172 & 76 & 93 & 81 \\
\hline Perilaku wisatawan menggunakan fasilitas wisata & 178 & 81 & 107 & 117 \\
\hline $\begin{array}{l}\text { Perilaku wisatawan menjaga kelestarian sumberdaya } \\
\text { alam }\end{array}$ & 166 & 83 & 113 & 117 \\
\hline $\begin{array}{l}\text { Perilaku wisatawan menjaga ketertiban dan } \\
\text { kenyamanan berwisata }\end{array}$ & 170 & 81 & 105 & 111 \\
\hline $\begin{array}{l}\text { Kepedulian wisatawan mengingatkan sesama } \\
\text { wisatawan }\end{array}$ & 148 & 73 & 88 & 96 \\
\hline TOTAL SKOR & 834 & 394 & 506 & 522 \\
\hline Skor tertinggi & 1250 & 850 & 925 & 975 \\
\hline Skor terendah & 250 & 170 & 185 & 195 \\
\hline KATEGORI & BAIK & BURUK & SEDANG & SEDANG \\
\hline
\end{tabular}

Hasilnya menunjukkan bahwa pengunjung di Wana Wisata Kawah Putih, memiliki perilaku yang positif terhadap lingkungan. Hal ini didukung oleh ketersediaan fasilitas interpretasi yang mengajak pengunjung untuk menjaga lingkungan. Sementara itu pengunjung TWA Situ Patenggang dan Bumi Perkemahan Ranca Upas, memiliki perilaku yang cukup, dalam artian belum sepenuhnya memahami pentingnya kualitas lingkungan. Dibeberapa lokasi masih ditemukan sampah yang berserakan, khususnya pada areal intensif, pusat konsentrasi pengunjung. Namun pengelola kawasan memiliki tim kebersihan yang cukup memadai sehingga kualitas lingkungannya relative baik. Pengunjung di TWA Cimanggu, memiliki perilaku yang paling buruk diantara pengunjung lokasi wisatawan lainnya. Hal ini didukung juga oleh pengelola kawasan yang kurang memperhatikan kebersihan dan penataan kawasan yang kurang sesuai. Selain itu banyaknya masyarakat sekitar yang berjualan di kawasan ini, menyebabkan pengawasannya menjadi kurang maksimal.

\section{c. Kriteria Intensitas Wisata di Wilayah Kluster Gunung Patuha}

Intensitas wisata ditentukan berdasarkan analisis tingkat kepadatan kawasan wisata dengan tingkat penggunaan kawasan wisata. Intensitas wisata ini menunjukkan sejauh mana kawasan wisata alam tersebut menerima tekanan akibat dari aktivitas pengunjung, sehingga dapat mempengaruhi kualitas lingkungannya. Perbandingan dilakukan dengan menggunakan tehnik skoring dan pengkategorian berdasarkan interval 3 kuartil, yaitu kategori intensitas tinggi, sedang dan rendah. Standar penentuan intensitas wisata terdapat pada tabel 4 . 
Tabel 4. Intensitas Wisata di Kawasan Wisata Alam Kluster Gunung Patuha

\begin{tabular}{|c|c|c|c|c|c|}
\hline No & Kawasan Wisata & $\begin{array}{c}\text { Tingkat } \\
\text { Kepadatan } \\
\text { Pengunjung } \\
(40 \%)\end{array}$ & $\begin{array}{c}\text { Tingkat } \\
\text { Penggunaan } \\
\text { Pengunjung } \\
(60 \%)\end{array}$ & Skor & $\begin{array}{c}\text { Kategori } \\
\text { Intensitas } \\
\text { Wisata }\end{array}$ \\
\hline 1 & $\begin{array}{l}\text { Wana Wisata } \\
\text { Kawah Putih }\end{array}$ & Tinggi & Baik & 1.8 & SEDANG \\
\hline 2 & TWA Cimanggu & Rendah & Buruk & 2.2 & SEDANG \\
\hline 3 & $\begin{array}{l}\text { Bumi Perkemahan } \\
\text { Ranca Upas }\end{array}$ & Rendah & Sedang & 1.6 & SEDANG \\
\hline 4 & $\begin{array}{l}\text { TWA Situ } \\
\text { Patengan }\end{array}$ & Rendah & Sedang & 1.6 & SEDANG \\
\hline
\end{tabular}

Khusus untuk TWA Cimanggu, aspek perilaku pengunjung yang buruk, perlu ditangani dengan khusus, karena dapat mempengaruhi kualitas lingkungan dengan signifikan. Pengawasan dari pengelola serta pemeliharaan kawasan perlu dilakukan secara rutin dan berkala, khususnya untuk aspek kebersihan dan keindahan kawasan.

\section{Model Pengelolaan Pengunjung di}

Wilayah Kluster Gunung Patuha

Hasil analisis terhadap kawasan lindung dan intensitas wisata menunjukkan adanya kombinasi kriteria kawasan wisata di kluster Gunung Patuha. Wana Wisata Kawah Putih dan TWA Situ Patengan merupakan kawasan wisata dengan persentase kawasan lindung yang cukup besar, serta memiliki intensitas wisata yang sedang.Sementara TWA Cimanggu dan Bumi Perkemahan Ranca Upas, merupakan kawasan wisata yang memiliki tingkat kerentanan yang rendah (bukan kategori kawasan lindung) dan intensitas wisata yang sedang. Namun demikian berdasarkan kajian terhadap kebijakan dan peraturan pemerintah mengenai penentuan status kawasan, pada wilayah kluster Gunung Patuha terdapat 2 kategori kawasan wisata yaitu kawasan konservasi dan pelestarian alam, yang meliputi kawasan TWA Cimanggu dan TWA Situ Patenggang, serta kawasan lindung yang meliputi Wana Wlsata Kawah Putih dan Bumi Perkemahan Ranca Upas.

Pengunjung harus dikelola dengan baik, sehingga tidak akan memberikan dampak negatif bagi kesenangan, pengalaman, dan pendidikan wisatawan serta bagi area yang dikunjungi. Jika diterapkan dengan benar maka teknik manajemen pengunjung juga dapat mengurangi biaya pemeliharaan dan meningkatkan pendapatan (Fielden and Jokilehto,1993; Checkland,P and Scholes, J $., 1990)$.

Tabel 5.Kriteria Pengelolaan Kawasan Wisata di Kluster Gunung Patuha

\begin{tabular}{|c|c|c|c|c|}
\hline No & $\begin{array}{c}\text { Kawasan Wisata } \\
\text { Alam }\end{array}$ & $\begin{array}{l}\text { Kriteria kawasan } \\
\text { berdasarkan hasil } \\
\text { analisis }\end{array}$ & $\begin{array}{c}\text { Kriteria kawasan } \\
\text { berdasarkan kebijakan } \\
\text { pemerintah RI }\end{array}$ & $\begin{array}{l}\text { Intensitas } \\
\text { wisata }\end{array}$ \\
\hline 1 & WW Kawah Putih & $\begin{array}{l}76 \% \text { kawasan } \\
\text { lindung }\end{array}$ & $\begin{array}{l}\text { Kawasan lindung } \\
\text { no. } 72 \text { tahun } 2010)\end{array}$ & Sedang \\
\hline 2 & TWA Cimanggu & $\begin{array}{l}12,4 \% \text { kawasan } \\
\text { lindung }\end{array}$ & $\begin{array}{l}\text { Kawasan konservasi dan } \\
\text { pelestarian alam } \\
\text { (PP no. } 36 \text { tahun 2010) }\end{array}$ & Sedang \\
\hline 3 & Buper Ranca Upas & $\begin{array}{l}0 \% \text { kawasan } \\
\text { lindung }\end{array}$ & $\begin{array}{l}\text { Kawasan lindung } \\
\text { (PP no. } 72 \text { tahun 2010) }\end{array}$ & Sedang \\
\hline 4 & $\begin{array}{l}\text { TWA Situ } \\
\text { Patenggang }\end{array}$ & $\begin{array}{l}11,6 \% \text { kawasan } \\
\text { lindung }\end{array}$ & $\begin{array}{l}\text { Kawasan konservasi dan } \\
\text { pelestarian alam } \\
\text { (PP no. } 36 \text { tahun 2010) }\end{array}$ & Sedang \\
\hline
\end{tabular}




\section{a. Pengaturan Pengunjung pada Kawasan Konservasi dan Pelestarian Alam dengan intensitas sedang - tinggi}

Berdasarkan hasil kajian kebijakan dan observasi, kawasan konservasi memiliki tingkat sensitifitas yang tinggi. Kawasan ini bukan hanya memiliki kepentingan ekologis sebagai ruang hidup atau habitat dari beberapa satwa dan vegetasi penting, namun juga memiliki peran dalam menjaga kestabilan lingkungan. Pengembangan wisata pada areal ini memerlukan pengawasan dan pengaturan yang ketat, baik dari aspek organisasi ruang (zonasi), ketentuan pembangunan dan jenis fasilitas, pengaturan pengunjung serta sistem pengawasannya. Tehnik yang dapat dilakukan untuk mengelola dampak pengunjung antara lain pengelolaan antrian pengunjung, meningkatkan kapasitas ruang, mengelola kapasitas ruang menjadi lebih fleksibel, memperkuat lahan, pengaturan kuota dan sistem ticketing (Fyall, A. et all, 2008: 167-172; Douglas, W, 2000). Khusus untuk aspek pengaturan pengunjung, maka hal yang harus diterapkan antara lain :

1). Membatasi akses menuju lokasi dan sumber daya tarik

Pembatasan itu bisa dalam bentuk mempersempit lebar jalan masuk, penggunaan material kasar seperti batuan besar sebagai dasar jalan (paving) atau membuka akses dengan kondisi lahan yang ekstrim dan relatiff curam. Secara tidak langsung, pembatasan akses akan menseleksi jumlah wisatawan yang masuk dan berminat untuk melihat obyek yang dimaksud. Sehingga diharapkan dengan jumlah pengunjung yang tidak terlalu banyak, maka dampak negative dan kerusakannya juga bisa diminimalisir.

2). Menerapkan desentralisasi fasilitasdan aktivitas pengunjung

Penyebaran atau desentralisasi fasilitas dan aktivitas pengunjung dilakukan dengan berbasiskan pada keragaman atraksi yang ada di kawasan wisata.Identifikasi atraksi dan daya tarik wisata harus dilakukan dengan sistematis untuk menghindari pemusatan fasilitas dan aktivitas wisata hanya pada satu daya tarik.

3). Mengembangkan fasilitas interpretasi berbasis pendidikan lingkungan

Hasil penelitian menunjukkan perilaku pengunjung yang relatif belum memahami pentingnya menjaga kebersihan dan kelestarian lingkungan. Hal ini memberikan implikasi pentingnya pengembangan program interpretasi yang dilengkapi dengan fasilitas dan media yang dapat mengedukasi pengunjung mengenai pentingnya kebersihan dan pelestarian lingkungan. Pengembangan program interpretasi ini menjadi sangat penting bagi kawasan yang memiliki kriteria intensitas wisata yang tinggi, khususnya dengan perilaku wisatawan yang buruk.

3). Menerapkan dan mengembangkan program wisata edukasi

Wisata alam dikawasan pegunungan memerlukan wawasan dan pengetahuan mengenai pentingnya menjaga lingkungan dan melestarikannya, sehingga pengelola memiliki kewajiban menerapkan program wisata edukasi yang dapat mentrasfer nilainilai pendidikan terhadap lingkungan. Pengembangan program difokuskan pada tercapainya nilai-nilai :

- Pembelajaran (learning) mengenai definisi, fungsi dan manfaat lingkungan alam bagi kehidupan manusia

- Pengkayaan (enriching) wawasan mengenai lingkungan alam dan keterkaitannya dalam ekosistem dan dinamika perubahan lingkungan

- Penghargaan (rewarding) terhadap alam yang ditunjukkan dengan aksi positif dalam menjaga dan melestarikan alam, seperti aksi membuang sampah pada tempatnya, membersihkan kawasan wisata dari sampah, menghindari penggunaan plastic, melakukan penanaman pohon, mempelajari budaya setempat dan sebagainya.

- Petualangan (adventuring) eksplorasi alam, melalui aktivitas wisata yang membangun rasa ingin tahu, eksplorasi 
keunikan dan sejarah terbentuknya, sehingga menimbulkan ketertarikan untuk melakukannya. Aktivitas wisata diarahkan kepada bentuk yang mendorong wisatawan untuk ikut berperan aktif bukan hanya sebagai subyek pasif.

\section{KESIMPULAN}

Keunikan dan kekayaan alam menjadikan tingginya potensi wisata alam di Indonesia. Pengembangan wisata alam di Indonesia difokuskan pada 2 kategori, yaitu wisata alam pegunungan dan wisata alam bahari. Karakteristik kawasan pegunungan, ternyata tidak hanya menarik secara estetika, memiliki keunikan gejala alam atau kelangkaan proses pembentukannya, namun juga memiliki kerawanan dan tingkat sensitifitas yang tinggi.

\section{DAFTAR PUSTAKA}

Checkland, P. and Scholes, J. (1990) Soft Systems Methodology in Action. John Wiley \& Sons, Chichester, UK.

Douglass, R.W. 2000. Forest Recreation. Waveland Press, Inc. Ohio State University. United States of America. p.389.
Feilden, B.M. and Jokilehto, J. (1993) Management Guidelinesfor World Cultural Heritage Sites, Rome: ICCROM.

Fyall, A., Brian Garrod, Anna Leask, Stephen Wanhill. 2008. Managing Visitor Attractions. Butterworth-Heinemann ELSEVIER. Burlington. USA. p.364.

Mason, Peter. 2003. Tourism Impacts, Planning and Management. ButterworthHeinemann. Linarce Hpuse, Jordan Hill, Oxford OX2 8DP. Burlington. p.195.

Pfluger, Yvonne. 2004. Value based decision Making Process for Strategic VisitorManagement in The Natura 2000 Area Lech River Valley, Tyrol. Proceedings of the Second International Conference on Monitoring and Management of Visitor Flows inRecreational and Protected Areas : Policies, Methods and Tools for Visitor Management. METLA. Finland. p.417.

Rafi'i, Suryatna. 1995. Meteorologi dan Klimatologi. Bandung: Angkasa. hal. 350.

Shackley, M. (2001) Managing Sacred Sites.Continuum, London. 